Interaksi Pesantren Dengan... | 53

\title{
INTERAKSI PESANTREN DENGAN SAINS DAN TEKNOLOGI
}

\author{
Muhammad Abror Rosyidin 1 * \\ 1 Program Pascasarjana Pendidikan Agama Islam, \\ Universitas Hasyim Asy'ari (UNHASY) Tebuireng \\ *E-mail: abror30031994@gmail.com
}

\begin{abstract}
However, along with the times, pesantren have not only opened religious-based schools, but also public schools that provide general knowledge (natural, social and language) to their students. Educational formalities in pesantren were also proposed so that pesantren alumni could continue their education to public schools. There are three main problems in this paper by reconstructing the pesantren education system, as follows; (1) the relationship between pesantren and the outside world, (2) the relationship between pesantren and science and technology, and (3) the epistemology of Islamic Science in Pesantren Sains (Trensains). Qualitative descriptive method is the choice in this study. This research is a qualitative field study with case studies. In order to obtain comprehensive data and pay attention to the relationship between the data and the focus and objectives of the research, data collection in this study used three techniques, namely (1) interviews, (2) participant observation: (3) research documentation. Research activities in data analysis include data reduction, data presentation, and drawing conclusions. From this research, it can be found that the interaction of science and technology with science cannot be denied. So pesantren must be prepared to deal with it. There are several Islamic boarding schools that have interacted with science and technology, both of which have greatly influenced the style of education, one of which is the Tebuireng Science Boarding School (Trensains). Santri are invited to study religion (Qur'an) as well as to study the verses of Kauniyah contained in it.
\end{abstract}

Keywords: Interaction, Pesantren, Science, Technology

\begin{abstract}
Abstrak
Sebagai lembaga keagamaan pesentren awalnya hanya mengajarkan ilmu agama saja. Namun seiring perkembangan zaman, pesantren tidak hanya membuka sekolah berbasis agama, namun juga sekolah umum yang memberikan ilmu pengetahuan umum (alam, sosial dan bahasa) kepada santrinya. Formalitas pendidikan di pesantren pun diajukan agar alumni pesantren dapat melanjutkan sekolah ke sekolah umum. Ada tiga permasalahan utama pada karya tulis ini dengan merekonstruksi ulang sistem pendidikan pesantren dengan tiga permasalahan utama sebagai berikut; (1) hubungan pesantren dengan dunia luar, (2) hubungan pesantren dengan sains dan tekonologi, dan (3) Epistimologi Sains Islam di Pesantren Sains (Trensains). Metode deskriptif kualitatif menjadi pilihan dalam penelitian ini. Riset ini merupakan studi lapangan kualitatif dengan studi kasus. Guna mendapatkan data yang komprehensif serta memperhatikan keterkaitan antara data dengan fokus serta tujuan penelitian, pengumpulan data dalam penelitian ini menggunakan tiga teknik, yaitu (1) wawancara, (2) partisipasi dalam observasi: (3) penelitian kepustakaan. Kegiatan penelitian dalam analisis data meliputi penyederhanaan data, penyajian data, dan penarikan kesimpulan. Dari penelitian ini, dapat ditemukan hasil bahwa interaksi sains dan teknologi dengan sains tidak bisa ditolak. Maka pesantren harus bersiap untuk menghadapinya. Ada beberapa pesantren yang telah berinteraksi dengan sains dan teknologi, bahkan keduanya sangat mempengaruhi corak pendidikan, salah satunya Pesantren Sains (Trensains) Tebuireng. Santri diajak untuk belajar agama (Alquran) sekaligus mengkaji ayat-ayat kauniyah yang terkandung di dalamnya.
\end{abstract}

Kata Kunci: Interaksi, Pesantren, Sains, Teknologi

Vol. 4, No. 1, Mei 2021 


\section{PENDAHULUAN}

Pesantren sebagai tempat berkembangnya ajaran agama Islam memiliki peran penting sebagai pusat peradaban Islam di masa lampau. Dari pesantren lahir cendikiawan- cendikiawan muslim, tokoh pejuang kemerdekaan, berbagai seni, tokoh pembaruan dan budaya-budaya Islam yang santun dan terpuji. Sebagai lembaga keagamaan pesentren awalnya hanya mengajarkan ilmu agama saja. Namun seiring perkembangan zaman, pesantren tidak hanya membuka sekolah berbasis agama, namun juga sekolah umum yang memberikan ilmu pengetahuan umum (alam, sosial dan bahasa) kepada santrinya. Formalitas pendidikan di pesantren pun diajukan agar alumni pesantren dapat melanjutkan sekolah ke sekolah umum.

Sebagai bagian penting dari kehidupan manusia, ilmu pengetahuan berkembang pesat sejak abad ke-19. Sejak itu, orang telah melakukan banyak eksperimen dan penemuan penting. Sebelumnya, ilmu ini telah mengalami berbagai revolusi estafet di berbagai negara seperti Yunani, Arab, India, China, Eropa dan Amerika. Sejak akhir abad ke-19 hingga saat ini (abad ke-21), obor ilmu pengetahuan berada di dunia Barat, memungkinkan mereka menguasai kemajuan ilmu pengetahuan dan teknologi saat ini. Namun bukan berarti mengabaikan potensi umat Islam, karena kita masih memiliki kitab suci yang selalu suci, Al-Quran al-Karim, yang juga banyak mengandung rahasia ilmiah.

Pada abad ke-7 M, Islam pertama kali mementingkan ilmu pengetahuan di Damaskus. Akibat perang yang berkecamuk, pusat ilmu pengetahuan Islam akhirnya pindah ke Bagdad, dan lahirlah ilmuwan-ilmuwan Muslim awal dari pesantren (ma'had), seperti Khawarizmo dan karya-karyanya yang sangat populer. Setelah itu, pusat perkembangan ilmu pengetahuan di dunia Islam pindah ke Barat, tepatnya di Kairo, dan akhirnya pusat ilmu pengetahuan Islam tiba di Spanyol setelah tahun 970 Masehi. Banyak buku-buku penting ilmu pengetahuan Islam diterjemahkan ke dalam bahasa inggris dan buku aslinya dibakar. Sejak saat itulah perkembangan ilmu pengetahuan dalam dunia Islam mengalami kemunduran.

Di sisi lain, kemajuan ilmu pengetahuan di Barat (negara-negara Barat) dengan cepat melewati budaya ilmiah tersebut. Ilmuwan besar mulai bermunculan. Sebagai contoh, dalam bidang fisika lahir nama Galileo yang kemudian dihukum oleh gereja karena pendapatnya bertentangan dengan gereja, Isaac Newton yang 
memperkenalkan teori gravitasi dan mekanika klasik, yang terakhir Albert Einstein dengan teori Relativitasnya yang mendasari mekanika kuantum (Atmaja, 2007).

Seiring kemunduran pendidikan Islam, perkembangan ilmu pengetahuan di Barat terus berjalan. Namun yang menjadi pertanyaan adalah apakah benar ilmu pengetahuan yang dikembangkan oleh Barat tersebut sudah benar dan sesuai dengan agama Islam? Banyak ilmuwan muslim yang berpendapat bahwa pengetahuan yang dikembangkan Barat adalah atheis, tidak bertuhan. Di sisi lain, banyak pesantren yang mencomot ilmu pengetahuan Barat tersebut untuk diterapkan pada pesatren modernnya. Padahal, dalam kitab suci umat Islam sendiri, Al-Quran, terdapat lebih dari 750 ayat kauniyah yang membicarakan sains. Sudah sepatutnya sebagai seorang muslim, sains yang kita dapatkan kita kembalikan pada Al-Quran, karenya hanya AlQuran-lah satu-satunya buku yang dijamin kebenarannya.

Melalui karya tulis ilmiah ini penulis berusaha untuk mengajukan beberapa solusi rekonstruksi pendidikan pesantren sebagai upaya memperbarui sistem pendidikan pesantren yang nantinya diharapkan mampu mengembalikan peran pesantren sebagai pusat peradaban, baik dalam ilmu keagamaan maupun sains yang Islami. Dua solusi yang diajukan untuk merekonstruksi pesantren adalah membangun budaya ilmiah yang telah dikembangkan dengan baik oleh Barat sehingga mereka mampu membangun ilmu pengetahuannya hingga seperti saat ini, dan hal tersebut juga sesuai dengan Al-Quran, serta Islamisasi sains, sebuah upaya membangun sains yang Islami, berdasarkan Al-Quran dan Al-Hadist.

\section{METODE}

Penelitian ini menggunakan pendekatan filosofis, guna menalar secara sistematis dan menyusun data dari sudut pandang tertentu (Irawati 2013). Jenis penelitian ini merupakan library research (studi kepustakaan) yaitu penelitian yang dilakukan dengan kajian bahan pustaka, di antaranya buku, ensiklopedi, jurnal, majalah \& asal pustaka lainnya yang berkaitan menggunakan utama bahasan atau perkara yang diteliti menjadi sumber data (Hadi 2005). Sebagai tambahan, peneliti juga melakukan wawancara terhadap pihak terkait yang disinyalir dapat memberikan data tambahan yang dibutuhkan.

Dalam penulisan penelitian diperlukan berbagai macam data, adapun macam data yang penulis sajikan dalam penulisan penelitian ini adalah data kualitatif berupa 
kepustakaan di antaranya adalah data mengenai interaksi pesantren dengan sains dan teknologi. Data tersebut diserap melalui referensi buku-buku, dan karya ilmiah lainnya yang ada kaitannya dengan penelitian ini. Untuk mengumpulkan data dalam penelitian ini, penulis menggunakan metode pencatatan.

Sehubungan dengan sumber data dalam penelitian ini adalah library research, maka data-data yang diperlukan berasal dari sumber-sumber yang terdapat pada kepustakaan. Data-data yang tadi diperoleh dikumpulkan dan disajikan dalam artikel ini dengan cara mengutipnya, baik secara langsung maupun tidak langsung. Oleh karena penelitian ini bertitiktolak pada studi analisis interaksi pesantren dengan sains dan teknologi, maka metode analisis yang penulis gunakan adalah metode normatif kualitatif, mengingat jenis datanya, maka jenis data yang dianalisis dengan menggunakan metode deskriptif analitis dan metode deduktif.

\section{HASIL DAN PEMBAHASAN}

\section{Hubungan Pesantren dengan Dunia Luar}

\section{Kondisi Pendidikan Islam}

Beberapa dekade yang lalu, Pendidikan Islam mejadi nomor dua, bahkan dahulu orang akan skeptis menyekolahkan anaknya di sekolah agama. Jika kita bertanya pada siswa yang baru lulus sekolah, entah itu baru lulus SD, SMP atau SMA untuk memilih melanjutkan ke sekolah agama atau sekolah umum, hampir kebanyakan mereka memilih untuk melanjutkan ke sekolah umum. Jika mereka tidak diterima di sekolah umum barulah mereka mau melanjutkan ke sekolah agama atau pesantren, atau jika mereka dipaksa oleh orang tua mereka untuk bersekolah di sekolah agama atau pesantren.

Minimnya minat pelajar untuk melanjutkan ke sekolah agama tak lepas dari prestasi sekolah berbasis agama yang surut. Baik madrasah Ibtidaiyah, Tsanawiyah maupun Aliyah kalah bersaing dengan sekolah umum yang setingkat. Karena banyak sekolah agama berada dalam lingkup pesantren, dan kebanyakan juga dimiliki oleh pesantren yang bersangkutan maka surutnya prestasi siswa ini tak bisa dilepaskan dari sistem pendidikan pesantren. Secara global, ada kekurangan pada sistem pendidikan Islam, termasuk sistem pendidikan pesantren, yang menyebabkan pendidikan berbasis agama kalah pamor dengan pendidikan umum, meski beberapa pesantren modern mampu 
menunjukkan menunjukkan eksistensi mereka bahwa mereka tidak kalah dengan sekolah umum, bahkan dengan sekolah favorit sekalipun.

Pembahasan berikutnya dapat dipersempit pada lingkup pendidikan pesantren karena sekolah berbasis agama Islam di luar pondok pesantren berada langsung di bawah naungan Kementrian Agama. Potensi pesantren dapat ditingkatkan sesuai perkembangan zaman, seperti halnya ketika pesantren berperan aktif dengan melahirkan pahlawan-pahlawan pejuang kemerdekaan, juga pahlawan-pahlawan pembangunan. Di era reformasi ini, pesantren juga harus bisa menggagas pahlawan-pahlawan peradaban. Namun, di era reformasi ini masih banyak pesantren yang menggunakan metode yang sama dengan apa yang mereka terapkan pada masa sebelum kemerdakaan ataupun masa-masa awal kemerdekaan republik ini.

\section{Perlunya Pesantren Berinteraksi dengan Dunia Luar}

Berpijak pada kondisi pesantren saat ini, seperti yang telah dijelaskan pada subbab sebelumnya, maka sistem pendidikan pesantren memang perlu ditata ulang. Pesantren harus mau menerima interaksi dari dunia di luar kebiasaan pesantren, selama itu berdampak positif. Era globalisasi telah memaksa kehidupan masuk pada perkembangan teknologi informasi. Jika santri tidak dapat mengakses, mungkin merekalah suatu saat nanti akan menjadi korban penyalahgunaan IT.

Rekontruksi interaksi pendidikan pesantren ini tidak lepas dari kelemahankelemahan pesantren, di mana kelemahan-kelemahan tersebut nantinya akan menghambat potensi pesantren sebagai pusat peradaban Islam. Di antara kelemahan-kelemahan pesantren, (Sugeng, 2009). Pertama, faktor kepemimpinan, di mana pesantren masih tegas memakai pola kepemimpinan yang sentralistik, atau terpusat pada figur kiai. Kedua, lemah dalam metodologi. Pesantren sangat kuat akar tradisinya di bidang penerapan literatur klasik. Ketiga, pesantren terjangkit penyakit disorientasi yang kehilangan banyak kemampuan dalam mengartikan dan menempatkan diri di tengah perubahan dan perkembangan zaman yang begitu cepat.

Berkaitan dengan permasalahan tersebut, khususnya pada poin pertama, dapat diajukan kurikulum yang terintegrasi sains, dengan dunia lain, misalnya pelajaran umum, advokasi, keterampilan, sains dan teknologi. Paling tidak, mau 
berinteraksi. Pesantren juga harus berani menerima tenaga ahli dari luar pesantren atau tenaga keluaran pesantren yang memiliki input yang baik bagi perkembangan pesantren. Misalnya saja ahli pendidikan, ahli IT, motivator, maupun pakar-pakar lain dalam bidang yang diperlukan untuk pengembangan.

Sesuai dengan dua sub-bab di atas, bahwa saat ini pendidikan pesantren sedang perlu berbenah dan memiliki beberapa kelemahan yang akan menghambat peran pesantren sebagai pusat peradaban Islam, oleh karenanya diperlukan rekonstruksi pendidikan pesantren untuk mengembalikan peran pesantren sebagai pusat peradaban Islam. Maka, paradigma pendidikan pesantren yang bagaimanakah yang dibutuhkan oleh pesantren? Tentunya paradigma pendidikan pesantren tersebut harus mampu menjadi tujuan dari sistem pendidikan pesantren itu sendiri, di mana tiap pesantren memiliki perbedaan visi dan misi, tapi umumnya seragam karena semua bersandar pada Al-Quran dan Al-Hadist, serta pendapat-pendapat para ulama.

Sesuai dengan apa yang diamanahkan oleh undang-undang dasar RI tahun 1945 bahwa salah satu kewajiban negara adalah mencerdaskan kehidupan bangsa, tentunya bagi umat Islam hal itu tidak sekedar cerdas/intelek namun juga harus Islami. Untuk menggapai tujuan tersebut sekaligus mengembalikan kejayaan Islam, maka paradigma pendidikan Islam pada umumnya atau pesantren khususnya (Anam,2003), yaitu 1) Menempatkan semua kegiatan pendidikan (talab al-ilmi) dalam kerangka agama, (2) Menjaga keseimbangan antara disiplin ilmu agama dan ilmu alam/ilmu umum, (3) Perlu diberikan kebebasan kepada civitas akademika untuk mengembangkankan sains secara menyeluruh untuk memainkan peran besar di semua bidang dan (4) Melaksanakan strategi pendidikan yang tepat guna.

Nurcholis Majid, tokoh Islam Indonesia yang juga alumni Pesantren Modern Gontor, pernah mengungkapkan pernyataan sebagai berikut (Sugeng, 2009):

"Pertumbuhan sistem pendidikan di Indonesia akan mengikuti jalur pesantren - pesantren itu Sehingga perguruan tinggi tidak berupa UI, $I P B$, UGM, Unair, Brawijaya, dan lain -lain, tetapi mungkin Universitas Tremas, Krapyak, Tebu Ireng, Bangkalan, Lasem, Gontor dan sebagainya. Setelah melihat dan membuat kiasan secara kasar dengan sistem pertumbuhan sistem pendidikan di negara-negara barat yang terkenal adalah berasal dari cikal bakal perguruan-perguruan keagamaan." 
Ada satu term menarik dari pemikiran Nurcholis Madjid atau Cak Nur tentang "Modernisasi adalah Rasionalisasi, bukan Westernisasi". Di situ Cak Nur mensesajarkan modern dengan rasional, yaitu perombakan pola pikir dan etos kerja lama yang tidak rasional diubah menjadi rasional. Pemikiran ini menurut Gus Sholah diperlukan, karena umat Islam, dalam perjalanan sejarahnya sendiri, tidak sanggup lagi membedakan nilai-nilai yang disangkanya islami itu, mana yang tresendental dan mana yang justru temporal. Cak Nur mendefinisikan sekularisasi bukan pada maksud penerapan sekularisme dan mengubah umat Islam menjadi sekularis, tetapi untuk menduniawikan nilai-nilai yang memang harus ditempatkan pada alam dunia, dan melepaskan umat Islam dari kecenderungan mengakhiratkannya.

Dalam hal ini sangat erat dengan pola pengembangan pesantren yang sejatinya dikenal memiliki jargon, "al-mukhafadlah ala al-qadimi ash-shalih wa alakhdzu bi al-jadid al-ashlah", mengambil tradisi lama yang masih baik, dan mengambil tradisi baru yang lebih baik (Wahid, 2011). Namun, Cak Nur kemudian melakukan kritik tajam kepada dunia pesantren dengan persoalanpersoalan yang mengintainya. Pertama dan yang paling utama, pesantren memiliki persoalan dalam menyuguhkan isi pesan moral yang harus disampaikan kepada masyarakat abad ini agar dapat terus relevan dan mempunyai daya tarik. Kedua, pesantren punya problem dalam penguasaan sesuatu yang kini berada di tangan orang lain, artinya pesantren telah terlambat dalam berkembang di saat orang lain sudah melakukan lompatan-lompatan tajam dalam menciptakan proses kehidupan (Majid, 1992).

Apa yang disampaikan Cak Nur, sebenarnya bukan hanya menjangkit pesantren, tapi juga dunia pendidikan Islam pada umumnya di mana penanaman nilai masih menjadi PR, dan masih terfokus pada bagaimana Islam diposisikan sebagai ajaran peribadatan kepada Tuhan semata. Akhirnya kemudian Cak Nur di dalam satu tulisannya mengatakan bahwa kehidupan di akhirat dan kehidupan di dunia berada pada dimensi masing-masing. Kehidupan di akhirat bersifat individual, tidak ada nilai-nilai kolektivitas atau solidaritas sosial antara sesama manusia, sedangkan dalam kehidupan di dunia hal itu sangat melekat dalam kehidupan manusia. Maka Cak Nur ingin mengatakan bahwa nilai-nilai Islam harus juga disandarkan pada betapa manusia harus tetap berhubungan erat 
dengan kemanusiaan, tidak serta-merta selalu mengakhiratkan kehidupan dunia. Akhlak, moral, etika, dan kehidupan dalam bermasyarakat, berbangsa, dan bernegara, juga perlu diinternalisasi dengan nilai-nilai Islami yang sebetulnya sudah disediakan Tuhan (Majid, 2008).

Cak Nur juga dengan tema besarnya, modernisasi, rasionalisasi, dan sekularisasi, juga membuat kita menjadi sedikit paham untuk memposisikan pesantren sebagai representasi dari pendidikan Islam endemik di Indonesia, di tengah arus pemikiran. Pesantren yang selama ini dipahami sebagai penjaga tradisi Islam Indonesia memiliki kaidah al-muhafadhatu ala al-qadimi ash-shalih wa al-akhdzu bi al-jadidi al-ashlah, menjaga tradisi yang lama yang masih bagus, dan mengambil tradisi baru yang lebih baik. Ini menunjukkan bahwa pesantren sangat epistemik, melakukan pengumpulan kembali serpihan-serpihan masa lalu ditinggalkan oleh pendahulu berupa tradisi dan ajaran-ajaran, kemudian merefleksikannya dengan kondisi sekarang sebagai upaya menyambut masa depan (Wahid, 2011).

Untuk menjadi pusat peradaban, pesantren tidak perlu menjadi atau memiliki universitas Islam. Namun yang terpenting pesantren harus mengaca pada Universtias Islam, baik di UIN/IAIN dan Universtias Islam lain baik di dalam negeri maupun luar negeri. Jika banyak IAIN yang berubah menjadi UIN untuk memperlebar bidang kajiannya, maka selayaknya hal ini juga diikuti oleh pesantren.

Poin terpenting lainnya adalah mengadopsi nilai-nilai ilmiah pada Universitas Islam dan menerapkannya pada pesantren, tidak hanya sekedar berganti nama. Budaya ilmiah inilah yang seharusnya dibangun di lingkungan pesantren karena budaya ini telah mengantarkan bangsa barat menjadi pusat peradaban saat ini. Topik membangun budaya ilmiah di lingkungan pesantren tersebut penulis ajukan sebagai salah satu upaya rekonstruksi menjadi pusat peradaban Islam di masa mendatang.

Selain itu, interaksi terhadap perkembangan masa juga perlu dilakukan. Pesantren harus sedikit banyak mengakomodir sains dan tekonologi dalam kehidupan sehari-hari, sebagai pengembangan pada pengetahuan. Tapi memang tidak bisa dipaksakan, karena perubahan yang besar tidak bisa dilakukan dengan waktu yang singkat. 


\section{Hubungan Pesantren dengan Sains}

Kita tidak sedang membahas jenis-jenis pesantren di Indonesia. Tetapi kita akan membahas satu di antara beberapa persinggungan terbaru antara pesantren dengan dunia luar berupa sains dan teknologi. Beberapa pesantren mengikuti perkembangan zaman, dengan mengkomodir disiplin ilmu selain agama, sebagai konsen utama, atau dipadukan dengan konsep agama.

Ada pesantren Sintesa, yang mengusung teknologi, ada pesantren Al Ittifaq yang mengusung wirausaha, ada pula yang mengusung tema sains dalam porsi yang besar, yaitu pesantren sains (Trensains). Konsep Sains ini terbilang merupaka trobosan baru dalam dunia pesantren, di mana biasanya santri hanya terfokus pada keilmuan agama. Karena makalah kita mengkrucut pada pembahasan soal interaksi pesantren dengan sains dan tekonologi, maka, penulis lebih fokus pada satu pembahasan soal model baru pesantren, yaitu pesantren sains.

Penggagas dari konsep pesantren ini, Dr. Agus Purwanto, dosen ITS Surabaya dan seorang pakar fisika, menginginkan adanya pesantren yang berbeda dengan pesantren yang lain. Pada umumnya pesantren hanya berfokus dalam kajian agama saja tanpa dikaitkan dengan ilmu modern. Kalaupun ada mungkin tidak dicari interaksi dengan sains dan tekhnologinya, tidak dicari titik temunya, hanya pada tataran mengajarkan dan mengembangkan.

Contoh seperti ini, pesantren sains itu mengkaitkan akidah dan kehidupan alam semesta yang nyata (sains). Umat Islam yakin bahwa semua ilmu pada umumnya berasal dari Sang Pencipta, Allah SWT. Sumber-sumber dan hukum-hukum Allah tidak mungkin bertentanagn dengan al Quran, khususnya ayat-ayat kauniyyah (alam/ sains). Pesantren sains memiliki semangat untuk membuktikan bahwa tidak ada pertentanagn antara ilmu agama dengan ilmu-ilmu umum atau sains. Bahkan keduanya sangat berhubungan dan berkaitan.

Sebelum Alquran turun, bangsa Yunani kuno sudah menemukan teori dan ilmu, tetapi masih berdasarkan akal dan indrawi saja yaitu teori geosentris bahwa bumi adalah pusat tata surya, sedangkan planet-planet lain itu mengelilingim bumi, dan ternyata bumi lah yang mengitari matahari yang berputar pada porosnya. Pengetahuan itu digambarkan Alquran dalam surat Yasin.

Alquran adalah petunjuk awal di mana manusia harus mencari potensinya, mencari kebenaran akidah dan menghubungkannya dengan sains dengan media yang 
sangat sederhana. Setelah Alquran turun berubah dan berpacu dengan Alquran dan sains. Walaupun belum banyak penemuan-penemuan kala itu, akan tetapi kala itu, cendekiawan muslim sangat kritis, seperti Al Farabi, Ibn Sina, al Kinder, Ibn Rusyd, Al Ghozali dan lain sebagainya. Bahkan kesemua ilmuan muslim itu, tidak mengesampingkan pengetahuan umum dan logika dengan agama, walaupun mereka lebih ahli di bidang agama. Maka dari situlah muncul adanya interaksi antara agama dan sains.

Dengan adanya interaksi agama dengan sains, maka terjadilah pertentangan antara teori ilmuan dahulu dengan ilmuan muslim kala itu, karena adanya penurunan dan peperangan kala itu. Kemudian ilmu-ilmu itu akhirnya dipisahkan karena banyak pertentanagan di antara ilmuan.

Setelah kita dapat mengetahui hubungan agama dan sains, maka sangat mudah menemukan benang merah, kenapa pesantren harus ambil alih peran untuk membumikan interaksi antara agama dan sains. Pesantren merupakan lembaga berbasis agama Islam dan merupakan lembaga pendidikan yang tertua di Indonesia. Ia turun temurun telah memberikan sumbangsih besar terhadap penyebaran agama Islam, hingga kemerdekaan bangsa ini. Seiring bertambahnya waktu, dunia berubah, dan tentu pesantren harus dapat berlari ikut ambil alih proses itu, untuk mengembangkan ilmu pengetahuan, tidak hanya ilmu agama saja.

Pesantren di sini sangat berperan penting dalam menjaga ilmu Allah khususnya agama dan sains yang sejatinya adalah satu. Maka dijadikan lah kolaborasi dan perpaduan. Santri pondok pesantren yang pada umumnya hanya belajar ilmu agama, lalu dalam konsep pesantren terbaru ini, dipadukan dengan ilmu pengetahuan dan sains. Tujuannya jelas, membentuk karakter dan akidah sebagai pondasi yang kuat serta berpengalaman dalam bekal menggapai masa depan, bukan hanya untuk santri, tapi untuk perkembangan ilmu pengetahuan dunia.

\section{Hubungan Pesantren dengan Teknologi Informasi dan Komunikasi}

Teknologi informasi dan komunikasi sangat penting bagi pesantren mengingat di dalam Islam sendiri harus saling bersilahturahmi antar sesama, kini cara untuk bersilahturahmi itu sendiri mendapatkan kemudahan dengan adanya teknologi yang dimana mendekatkan dan memudahkan untuk saling berkomunikasi. Dalam hal ini, seorang santri dan santriwati juga perlu mempunyai keterampilan dalam penggunaan 
alat teknologi, karena minat dan bakat peserta didik di dalam pesantren juga perlu diasah.

Teknologi sendiri sangat penting bagi mereka yang ingin melakukan kegiatan bekerja dan saling silahturahmi antar keluarga maupun antar temannya. Teknologi sendiri membantu para santri bersaing dengan masyarakat luas di dalam perekonomian. Karakter kemodernan berikutnya adalah sifat fleksibel dan dinamis, berarti tidak membakukan segala sesuatu atau membekukan segala sesuatu (Yusuf, 2004:170).

Perkembangan era teknologi semakin maju dan pesat dalam lingkup sosial, teknologi kini sangat membantu perkembangan seseorang untuk saling berinteraksi satu sama lain. Teknologi merupakan bagian dari gaya hidup masyarakat di seluruh dunia untuk saling mencari informasi dan menyerap informasi yang ada. Informasi yang diberikan sangatlah penting untuk kemajuan berpikir dari masyarakat itu sendiri. Pendidikan yang berbasis teknologi dalam hal ini sangat penting untuk menunjang aktifitas pembelajaran.

Pesantren dalam hal ini penting untuk memberikan wawasan teknologi informasi dan komunikasi kepada peserta didik di pesantren, karena di dalam kegiatan pesantren merupakan kegiatan pembelajaran. Teknologi sangatlah membantu untuk perkembangan masyarakat untuk saling berinteraksi dan menerima informasi dari luar, dan perlu ada batasan dalam penggunaannya.

Pembatasan informasi sangatlah penting, agar terhindarnya dari informasi yang kurang bermanfaat. Dalam uraian yang telah disebutkan, maka para santri dan santriwati perlu diberikan sebuah informasi tentang pentingnya teknologi informasi dan komunikasi.

Dalam kaitannya dengan sains, TIK ini merupakan terapannya. Sains adalah tararan teori yang dapat meningkatkan pola pikir ilmiah dan terintegrasi secara luas, sedangkan teknologi dapat membantu santri menangkap informasi positif dan tentunya syiar agama atau dakwah juga semakin luas dapat dijangkau. Contohnya saja, film, media, jurnalistik, fotografi, videografi, sinematografi, desain grafis, robotik dll sebagainya. Maka sangat perlu dipresiasi jika ada pesantren yang dapat mengakomodir TIK ke dalam pembelajarannya.

Misalnya saja, di Tebuireng, selain santri dibekali ilmu agama melalui pengajian kitab dan Alquran, mereka juga diberikan wadah untuk berkreasi, salah satunya ada 
Kopi Ireng, Komunitas Photography Tebuireng yang berkecimpung di dalam pengembangan pengetahuan soal foto, video, dan film. Mereka bahkan telah belajar untuk membuat film berdurasi panjang. Lalu Tebuireng membuat Rumah Produksi Tebuireng yang telah memproduksi tiga film, salah satunya yang sedang ramai, Jejak Langkah 2 Ulama. Tentu media dakwah semakin bisa menyeluruh.

Di Tebuireng santri juga diajari menulis, jurnalistik, media, dan implementasi perkembangan TIK lainnya. Bahkan beberapa waktu lali diadakan diklat Coding bekerjasama dengan Telkom Indonesia. Para pembina, mahasiswa, dan santri diajari bagaimana mengelola website, coding, bahkan sampai tataran hack ringan. Hal itu dapat menjadi positif karena sekarang ini, rawan akun-akun di media sosial yang terkena retas, dan kita tidak bisa berkutik jika tidak menguasi hal-hal itu.

Satu lagi Pesantren Sintesa di Magetan Jawa Timur. Pesantren ini terbilang unik, di mana santri-santrinya adalah generasi yang siap kerja. Mereka dibekali ilmu IT untuk mengembangkan ekonomi kreatif atau industri kreatif di jalur online. Mereka dituntun bisa coding, lihai komputer, website, dan bahkan sekalian bisnis online. Mereka digembleng tentang membangun website, menjadi SEO Marketing, memainkan Facebook Marketing, dan Google AdWords. Tetapi mereka juga dituntut untuk belajar agama, kajian, bahkan ada program tahfidzul quran atau menghafal Alquran.

Di Bantul Yogyakarta, ada pesantren bernama Pesantren IT. Dalam pendidikan IT, pesantren ini membagi jurusannya menjadi beberapa keahlian. Banyak keahlian yang ada di Pondok IT, di antaranya adalah Pondok Programmer, Pondok Multimedia, Pondok Imers, Pondok Cyber, dan masih banyak lagi. Terlepas dari aliran dan afiliasi ormas, mereka sangat progresif dan mandiri, di mana santri baru dibiayai oleh kakak kelas mereka yang sudah menghasilkan uang dari pekerjaan IT mereka. Bisa dikatakan santri gratis masuk, lalu diajari IT sampai menghasilkan uang. Setelah itu mereka dapat membantu adik kelasnya belajar dengan gratis.

\section{Konsep Pesantren Sains (Terensains)}

Trensains (Pesantren Sains) diprakarsai oleh Agus Purwanto, pada 2013. Ia merupakan dosen Fisiki Teori Institute Teknologi Sepuluh November (ITS) Surabaya. Tujuan utamanya, yaitu untuk melahirkan generasi yagn tidak sekedar mampu dalam bidang sains, tapi juga punya basis keagamaan yang kaut, serta menempatkan AlQuran sebagai sumber dalam mengembangkan sains. Ia seorang aktivis 
Muhammadiyah dalam Majelis Tarjih dan menggagas pula SMA Trensains milik Muhammadiyah di Sragen Jawa Tengah.

Atas kerjasamanya dengan KH. Salahuddin Wahid, Pengasuh Pesantren Tebuireng Jombang periode 2006-2020, didirikanlah sekolah baru di bawah naungan Yayasan Hasyim Asy'ari Tebuireng, yaitu SMA Trensains Tebuireng pada 2014 seiring dibangunnya Pesantren Tebuireng Cabang 2 di Jombok Ngoro Jombang. Pada awal berdiri, empat kelas menjadi serajah awal santri generasi pertama belajar sains dan AlQuran.

Saking besarnya keinginan Gus Sholah agar dikotomi ilmu agama dan ilmu non agama, yang berujung pada stigma bahwa ilmu non agama bukan berorientasi pada ukhrawi (akhirat), Gus Sholah mengawinkan ilmu agama (Alquran) dengan ilmu non agama (Sains-Teknologi) dalam satu bingkai pesantren. Upaya ini, hemat peneliti, merupakan bagian dari konsekuensi dari pemikiran Gus Sholah tentang perpaduan keislaman dan keindonesiaan, sebagaimana yang dikatakan oleh Asisten Pribadi Gus Sholah, Aminuddin Aziz saat diwawancarai oleh peneliti, di mana santri selain diajarkan ilmu agama untuk menjadi muslim yang baik, juga harus menjadi sosok yang membanggakan negaranya dengan ikut serta mengembangkan sains-teknologi yang ke depan akan sangat ramai diperebutkan.

Perpaduan Islam dan Indonesia tidak melulu soal keagamaan dan kebangsaan, tetapi magnet santri (representasi dari pendidikan Islam) terhadap upaya memajukan negara (kebangsaan) juga bagian dari peran pesantren dalam mengawinkan Islam dan Indonesia. Di SMA Trensains, santri diajak untuk mengkaji ayat-ayat kauniyah dalam Al Quran tentang alam semesta dipadukan dengan sains kealaman.

Pada perkembangannya, tidak hanya strata SLTA, untuk persiapan menuju kematangan SMA Trensains yang fokus mengakaji Al-Quran dan Sains, Gus Sholah mendirikan SMP Sains Tebuireng pada tahun 2018. Sekolah ini terletak di Pesantren Tebuireng Cabang ke-2 di Jombok Ngoro Jombang, atau berada dalam satu komplek dengan SMA Trensains. Dari sekolah ini Gus Sholah mengharapkan munculnya embrioembrio ilmuwan muslim yang bisa mewarnai peradaban dunia dengan tetap memegang teguh Al Qur'an dan mempunyai keluhuran akhlak.

Interaksi pesantren dengan sains dan teknologi, ada kaitannya dengan dualisme pendidikan, dalam hal ini pendidikan agama dan nasional, banyak yang menuduhkan hal itu kepada Kementerian Agama, padahal menurut Gus Sholah apa yang dilakukan 
Kemenag sudah tepat. Buktinya hingga sekarang, masyarakat dapat menikmati buah kebijakan itu, misalnya majunya madrasah-madrasah, pesantren-pesantren, dan diniyah-diniyah yang dapat menampung anak-anak generasi muslim untuk memperdalam agama. Bisa dibayangkan bagaimana jika pendidikan agama hanya diatur oleh Kementerian Pendidikan saja. Berapa porsi yang akan diberikan. Tentu tidak bisa seluas Kemenag dalam memberikan porsinya. Lagipula siapa yang akan mengurus madrasah, diniyah, TPQ, dan pesantren?

Walaupun di negara ini ada Ormas misal NU dan Muhammadiyah yang mengurus beberapa lembaga di dalam naungan mereka, atau dianggap berafiliasi dengan ormas mereka, tetapi tidak bisa menjangkau secara luas, terutama sekolah-sekolah yang didirikan dan dikelola oleh swasta. Selain itu juga bisa menyebabkan negera tidak hadir dalam mengurusi pendidikan agama secara luas dan menyeluruh. Dan ini mengganggu proses integrasi Islam dan Indonesia dalam kaitannya dengan pendidikan.

Adanya pendidikan agama dan pendidikan umum, juga dapat menggerus anggapan bahwa ilmu non-agama atau ilmu umum tidak ada kaitannya dengan urusan ukhrawi (akhirat). Sementara ilmu agama adalah yang paling dekat dengan akhirat. Dikotomi semacam ini masih banyak terjadi di masyarakat, walau jumlahnya sudah berkurang dibandingkan masa lalu. Maka di madrasah-madrasah, di pesantrenpesantren, dan perguruan tinggi Islam, juga diajarkan ilmu-ilmu umum, seperti Matematika, Sains-Teknologi, ilmu-ilmu sosial, dan lain-lain.

Di UIN misalnya, diadakan jurusan-jurasan ilmu-ilmu umum, seperti teknik sipil, ekonomi, sosial politik, MIPA, teknik mesin, teknik bangunan, bahasa asing non Arab, Bahasa Indonesia, bahasa Daerah, dan lain-lain. Tentu ini bagus untuk membantu proses integrasi yang manis antara menjadi muslim yang berwawasan agama yang mumpuni dan menjadi generasi penerus bangsa yang ikut serta mewarnai pergerakan keilmuan yang ada. Apakah sudah sukses? Kembali lagi kepada penyelenggaraannya. Gus Sholah menyebut proses semacam ini tidak bisa terjadi cepat. Perlu waktu lama dan berkelanjutan agar dapat dikatakan sukses. Tapi minimal wadah untuk mengarah ke sana telah disediakan.

Umat Islam, menurut Gus Sholah, masih sangat kurang dalam mempelajari Alquran dalam kaitannya dengan kajian ilmu pengetahuan. Padahal dalam Alquran terdapat sekitar 800 ayat yang berkisah tentang alam semesta dan itu belum menjadi 
perhatian umat Islam. Mereka masih fokus pada ayat-ayat yang bicara tentang hukum Islam yang hanya memenuhi sekitar 200-300 ayat saja dalam Al Quran. Umat nonmuslim yang justru menggalakkan spirit mengkaji Al Quran dari sisi sains. Untuk itu, Gus Sholah dengan adanya SMA Trensains ini berharap agar ada golongan umat Islam di Indonesia ini yang memperhatikan fenomena alam sebagai bagian dari anugerah Tuhan yang diselipkan dalam ilmu pengetahuan. Alumni Trensains diharapkan mampu mengawal harapan Gus Sholah itu. Enam angkatan telah diluluskan oleh lembaga pendidikan ini. Mereka sedang belajar di kampus-kampus ternama di negeri dan bahkan ke luar negeri membawa semangat perpaduan Islam (Alquran) dan Sains sebagi bagian dari upaya memajukan umat Islam dan Indonesia.

Trensains tidak sekedar mencampurkan kurikulum pesantren dengan ilmu umum sebagaimana pesantren modern atau posmodern, tetapi juga mengambil kekhususan mengkaji Al-Quran dan hadis yang dipadukan dengan sains kealaman, serta bagaimana pola interaksi keduanya. Pola interaksi antara agama dan sains ini tidak ditemukan di pesantren modern.

Keahlian bahasa asing, terutama Arab dan Inggris menjadi prasarat dasar yang tidak bisa ditawar. Mereka tidak hanya dituntut memiliki keahlian nalar matematis dan filsafat saja. Hal itu dikarekan proyeksi ke depan yang cukup besar, di mana alumninya diharapkan menjadi ilmuan sains kealaman, teknolog, serta dokter yang memiliki basic Al-Quran dan keagamaan yang kuat.

Semenjak ditetapkan oleh Menteri Agama RI bertepatan pada 23 Agustus 2014 (19 Syawal 1935 H), SMA Trensains Tebuireng jadi perhatian banyak kalangan, tidak hanya dari kalangan pesantren saja, tetapi juga golongan akademisi, praktisi pendidikan, praktisi sains, tekonlog, dan lain sebagainya. Mereka ikut bersemangat mengikuti alur pertumbuhan penerapan pendidikan SMA Trensain yang menjadi salah satu sekolah yang menggawangi gagasan Pesantren Sains (Trensains)". Banyak kalangan calon magister, calon doktor, peneliti, maupun lembaga pendidikan lain yang ingin menjadikan SMA Trensains sebagai lokasi penelitian dan studi banding.

Bagi beberapa kalangan, Trensains dianggap sebagai bagian dari satu upaya terbarukan yang dapat meningkatkan kualitas pendidikan pesantren. Sementara yang lain, berpendapat bahwa Trensains bisa menjadi agen revolusi pendidikan pesantren di masa sekarang dan masa depan. Hal ini karena Trensains menerapkan kurikulum pembelajaran yang berangkat dari konsep Pesantren Sains itu sendiri. Selain itu, mata 
pelajaran filsafat yang diajarkan kepada para santrinya, juga ikut serta menjadikannya punya ciri khas atau hal baru dua dunia pesantren.

Umat Islam sekarang ini berada dalam cengkraman dominasi Barat dalam bidang sains dan teknologi. Sejajar dengan perkembangan itu, malah terjadi kemunduran di dalam aspek sosial, moral, dan peradaban yang cukup memeriskan. Alam berada pada kondisi rusak secara masif juga ikut memperparahnya. Itu ditengerai merupakan akibat negatif dari kemajuan sains dan teknologi itu sendiri. Untuk itu, Trensains menerpakna sains dan teknologi yang berbasis wahyu dan kitab suci. Itu merupakan ikhtiar agar dapat mengatasi problematika kompleks dunia tersebut.

\section{Epistemologi Sains Islam di SMA Trensains Tebuireng}

Epistemologi (Ghofur, 2016, 653) merupakan cabang filsafat yang berhubungan dengan pelacakan hakikat serta keberanan pengetahuan, dengan meneliti sumber, ketentuan, dan proses pembentukan pengetahuan itu sendiri. Dalam kelanjutannya, epistimologi tidak bisa dilepaskan dari sumber ilmu pengetahuan dan teori tentang kebenaran, sehingga ia menjelaskan suatu pengetahuan itu bagaimana bisa dapat diperoleh.

Sains Barat (modern) pula dibentuk lewat tiga pilar, yaitu ontologi, aksiologi, dan epistimologi. Namun, Barat membangun sains dengan melenyapkan entitas wahyu. Peran agama menjadi hilang seiring waktu. Materialisme menjadi intisari ontologi sains barat. Pada kenyataannya cuma terdiri dari modul, ruang, dan waktu, sedangkan jiwa hanya diposisikan sebagai sekumpulan

Dalam aksiologi sains barat, materialisme telah membuang transendensi sains, juga menyingkirkan tujuan akhir sains. Keadaan ini membuat para ilmuwan hanya takjub dengan dirinya sendiri ketika berhasil mengungkap rahasia alam semesta, akibatnya para ilmuwan terjebak dalam kondisi nihilisme, kehampaan ruhaniah, dan kekosongan spiritual.

Di sisi yang lain, epistemologi dalam sains modern hanya terbatas pada metodeilmiah dan menolak wahyu sebagai salah satu sumber serta petunjuk dalampengembangan sains. Hal inilah yang ditegarai menjadi musabab bagi sains baratyang berkembang saat ini bahwa sains hanyalah untuk sains itu sendiri, sehinggatidak heran jika terdapat banyak ilmuwan-ilmuwan merasa kering ruhani sertaspiritualnya ditengah capaiannya yang sangat luar biasa. 
Pada aspek yang lain, berdasarkan fakta saat ini seiring dengan kemajuan dan perkembangan sains barat terjadi pula kemerosotan akhlak, sosial, moral, dan peradaban yang justru menjadi bencana bagi manusia-manusia modern. Kondisi inilah yang melatarbelakangi berdirinya lembaga-lembaga pendidikan sebagai penerap konsep atau gagasan "Pesantren Sains" dimana lembaga pendidikan tersebut sebagai ujung tombak dalam penerapan sains Islam.

Epistemologi sains Islam dalam gagasan Trensains, menjelaskan bahwa al-Quran dapat dikonfirmasi kebenarannya oleh fenomena alam dan diri manusia, artinya bahwa al-Quran dapat menjadi sumber informasi bagi suatu fenomena alam, atau alQuran dapat menjadi basis bagi bangunan teori tentang alam.

Maksudnya adalah dalam epistemologi sains Islam, wahyu dan sunnah adalah sumber yang memberikan inspirasi bagi pembangunan ilmu pengetahuan, dimana ayat-ayat kauniyah digunakan sebagai konstruksi sekaligus sumber dalam pengembangan sains serta pola penyelenggaraan pendidikannya.

Dengan demikian, diharapkan bangunan epistemologi sains Islam untuk ilmu pengetahuanakan melahirkan generasi Muslim yang shalih dalam bidang agama dan ahli dalam bidang ilmu pengetahuan dan teknologi, yang pada gilirannya akan memberikan dampak bagi kejayaan peradaban Islam di masa yang akan datang serta bangsa Indonesia dan dunia internasional pada umumnya.

Dalam aksiologi sains barat, materialisme sudah membuang transendensi sains, juga menyingkirkan tujuan akhir sains. Keadaan ini menghasilkan para ilmuwan yang hanya takjub terhadap dirinya sendiri saat berhasil mengungkap misteri alam semesta, akibatnya para ilmuwan terjebak dalam syarat nihilisme, kehampaan ruhaniah, serta kekosongan spiritual.

Pada sisi yang lain, epistemologi dalam sains terbaru hanya terbatas di metode ilmiah dan menolak wahyu menjadi keliru satu asal dan petunjuk dalam pengembangan sains. Hal inilah yang dicurigai menjadi musabab bagi sains Barat yang berkembang saat ini bahwa sains hanyalah buat sains itu sendiri, sehingga tidak heran, bila terdapat banyak ilmuwan-ilmuwan merasa kemarau rohani serta spiritualnya di tengah capaiannya yang sangat luar biasa.

Di aspek yang lain, seiring kemajuan dan perkembangan sains Barat terjadi jua kemerosotan akhlak, sosial, moral, dan peradaban yang justru menjadi bencana bagi manusia-manusia modern. Syarat inilah yang melatarbelakangi berdirinya forum- 
forum pendidikan menjadi penerap konsep atau gagasan "Pesantren Sains" di mana lembaga pendidikan tersebut sebagai ujung tombak dalam penerapan sains Islam.

Epistemologi sains Islam pada gagasan Trensains, mengungkapkan bahwa alQuran bisa dikonfirmasi kebenarannya dalam fenomena alam serta kemanusiaan, yakni bahwa al-Quran bisa menjadi sumber pembahasan bagi suatu kenyataan alam, atau al-Quran dapat menjadi pusat bangunan teori tentang alam.

Maksudnya, dalam epistemologi sains Islam, wahyu dan sunnah diposisikan seabgai asal yang memberikan ilham bagi pembangunan ilmu pengetahuan, di mana ayat-ayat kauniyah dipergunakan sebagai konstruksi sekaligus sumber dalam pengembangan sains serta pola penyelenggaraan pendidikannya.

Dengan demikian, dibutuhkan bangunan epistemologi sains Islam untuk ilmu pengetahuan yang akan melahirkan generasi Muslim yang saleh pada bidang agama dan pakar pada bidang ilmu pengetahuan dan teknologi, yang pada gilirannya nanti akan berdampak bagi kejayaan peradaban Islam pada masa yang akan tiba dan juga bagi bangsa Indonesia dan dunia internasional pada umumnya.

\section{SIMPULAN DAN SARAN}

\section{Simpulan}

Simpulan dapat bersifat generalisasi temuan sesuai permasalahan penelitian, dapat pula berupa rekomendatif untuk langkah selanjutnya.

Dengan perkembangan zaman yang pesat, pesantren harus melakukan beberapa hal, (1) menempatkan semua kegiatan pendidikan dalam kerangka agama, (2) menjaga keseimbangan antara disiplin ilmu agama dan ilmu alam/ilmu umum, (3) perlu diberikan kebebasan kepada civitas akademika untuk mengembangkankan sains secara menyeluruh untuk memainkan peran besar di semua bidang dan (4) melaksanakan strategi pendidikan yang tepat guna.

Selain itu, interaksi terhadap perkembangan masa juga perlu dilakukan. Pesantren harus sedikit banyak mengakomodir sains dan tekonologi dalam kehidupan sehari-hari, sebagai pengembangan pada pengetahuan. Tapi memang tidak bisa dipaksakan, karena perubahan yang revolusioner tidak bisa dijajaki dalam waktu yang kilat.

Pesantren di sini sangat berperan penting dalam menjaga ilmu Allah khususnya agama dan sains yang sejatinya adalah satu. Maka dijadikan lah kolaborasi dan 
perpaduan. Santri pondok pesantren yang pada umumnya hanya belajar ilmu agama, lalu dalam konsep pesantren terbaru ini, dipadukan dengan ilmu pengetahuan dan sains. Tujuannya jelas, membentuk karakter dan akidah sebagai pondasi yang kuat serta berpengalaman dalam bekal menggapai masa depan, bukan hanya untuk santri, tapi untuk perkembangan ilmu pengetahuan dunia.

Pesantren dalam hal ini penting untuk memberikan wawasan teknologi informasi dan komunikasi kepada peserta didik di pesantren, karena di dalam kegiatan pesantren merupakan kegiatan pembelajaran. Teknologi sangatlah membantu untuk perkembangan masyarakat untuk saling berinteraksi dan menerima informasi dari luar, dan perlu ada batasan dalam penggunaannya. Pembatasan informasi sangatlah penting, agar terhindarnya dari informasi yang kurang bermanfaat. Dalam uraian yang telah disebutkan, maka para santri dan santriwati perlu diberikan sebuah informasi tentang pentingnya teknologi informasi dan komunikasi.

Salah satu pesantren yang membangun interaksi dengan sains dan teknologi, yaitu pesantren sains (Trensains), dan salah satu yang sedang berkembang adalah Pesantren Sains Tebuireng yang digagas oleh KH. Salahuddin Wahid (Gus Sholah) di Jombok Ngoro Jombang. Trensains (Pesantren Sains) ialah konsep pembelajaran yang tidak mencampurkan modul pesantren dengan ilmu umum sebagaimana pesantren modern. Trensains mengambil kekhususan pada uraian al-Quran, hadis serta sains kealaman, serta pola interaksinya. Poin terakhir, interaksi antara agama serta sains ialah modul khas Trensains yang tidak ditemukan pada pesantren modern.

Bangunan epistemologi sains Islam untuk ilmu pengetahuan yang akan melahirkan generasi muslim yang saleh pada bidang agama dan pakar pada bidang ilmu pengetahuan dan teknologi, yang pada gilirannya nanti akan berdampak bagi kejayaan peradaban Islam pada masa yang akan tiba dan juga bagi bangsa Indonesia dan dunia internasional pada umumnya.

\section{Saran}

Berikut adalah beberapa saran kami terhadap permasalahan yang ada. Pertama, pemerintah, terutama Kemenaker, Kemenag, Kemendikbud, dan lembaga terkait, harus hadir kepada pesantren dengan memberikan bantuan, pelatihan, dan peralatan untuk pengembangan Sains dan Teknologi. Kedua, pesantren harus membuka diri terhadap dunia luar, terutama terhadap sains dan teknologi, beserta dengan orangorang yang ahli di bidang-bidang itu. Ketiga, pihak-pihak swasta yang mempunyai dana 
CSR, khusunya perusahaan di bidang sains dan teknologi, harus dapat berkontribusi membantu santri dan pesantren mengembangkan bidang-bidang garapan di era industri kreatif.

\section{DAFTAR PUSTAKA}

Amirul, Hadi. (2005). Metodelogi Penelitian Tindakan. Bandung: CV Pustaka Setia.

Anam, MK. 2003. Melacak Paradigma Pendidikan Islam (Artikel, sumber: http://researchengines.com/mk-anam.html, diakses pada: 25 Agustus 2010).

Atmaja, 2007. Studi Kelayakan Teori dan Aplikasi. Jakarta: Alex Media Komputindo.

Aziz, Aminuddin. Komunikasi Pribadi. 27 Juli 2021.

Ghofur, Abdul. 2016. Konsep Pesantren Sains (Trensains), Reinformasi Pembelajaran Sains pada Sistem Pendidikan Berbasis Pesantren. dalam "Mengubah Karya Akademik Menjadi Karya Bernilai Ekonomi Tinggi”. Surabaya: Prodi Pendidikan Sains Pascasarjana UNESA.

Ghofur, Abdul. Komunikasi Pribadi. 2 Agustus 2021

Katsoff, Louis O. dalam Yuni Irawati. 2013. Metode Pendidikan Karakter Terhadap Mahasiswa dalam Menyelesaikan Tugas Akhir. Solo: PT Indeks

Madjid, Nurcholis. 1992. Bilik-Bilik Pesantren. Jakarta: Paramadina.

Madjid, Nurcholis. 2008. Islam, Kemodernan dan Keindonesiaan. Bandung: Mizan.

Purwanto, Agus. 2008. Ayat-ayat Semesta: Sisi-sisi Al-Qur'an yang Terlupakan. Bandung: Penerbit Mizan.

Riyadi, Sugeng. 2009. Tipologi Pemikiran Pembaruan Pendidikan Islam di Indonesia. Yogyakarta: Magister Studi Islam UII.

Sanaky, Hujair AH. 2008. Pemikiran dan Peradaban Islam (Materi/Bahan MK). Yogyakarta: FIAI UII.

Tim Website SMA Trensains. Profil SMA Trensains. https://www.smatrensains.sch.id/2021/05/sma-trensains-tebuirengpesantren-sains/. Diakses pada 28 Juli 2021).

Trimanda, Andi. 2008. Budaya Ilmiah dalam Komunitas Ilmiah. (Artikel online, sumber: ttp://trinanda.wordpress.com/2008/06/05/budaya-ilmiah-dalam-komunitasilmiah.html, akses on 20 Agustus 2010).

Wahid, Salahuddin. 2011. Berguru Pada Realitas, Refleksi Pemikiran Menuju Indonesia Bermartabat. Malang: UIN-Maliki Press. 
Wahid, Salahuddin. 2011. Transformasi Pesantren Tebuireng, Menjaga Tradisi di Tengah Tantangan. Malang: UIN-Maliki Press.

Wahid, Salahuddin. 2017. Memadukan Keislaman dan Keindonesiaan, Esai-Esai Kebangsaan, Jombang: Pustaka Tebuireng.

Widjajakusuma, MK. 2008. Trend Perkembangan Ilmu di Barat dan di Timur. Perpustakaan Nasional: Katalog Dalam Terbitan (KTD).

Yusuf, S. 2004. Psikologi Perkembangan Anak dan Remaja. Bandung: PT. Remaja Rosdakarya 